\title{
Role of prey subcellular distribution on the bioaccumulation of yttrium $(Y)$ in the rainbow trout.
}

Authors: Pierre-Yves Cardon ${ }^{1}$, Olivier Roques ${ }^{2}$, Antoine Caron ${ }^{1}$, Maikel Rosabal ${ }^{3}$, Claude Fortin ${ }^{4}$, and Marc Amyot ${ }^{1 *}$

1 GRIL, Université de Montréal (UdeM), Département de sciences biologiques, Complexe des sciences, C.P. 6128, succ. Centre-Ville, Montréal (Québec), Canada, H3C $3 \mathrm{~J} 7$

${ }^{2}$ Université de La Rochelle, Faculté des sciences et technologies, avenue Michel Crépeau, La Rochelle, France, 17042

3 GRIL, Université du Québec à Montréal (UQAM), Département des sciences biologiques, 141 avenue du Président-Kennedy, Montréal (Québec), Canada, H2X 1Y4

${ }^{4}$ Institut National de la Recherche Scientifique, Centre Eau Terre Environnement (INRSETE), 490 rue de la Couronne, Québec (Québec), Canada, G1K 9A9

*Corresponding author: e-mail address: m.amyot@umontreal.ca; Phone 1-514-343-7496. GRIL, Université de Montréal (UdeM), Département de sciences biologiques, Complexe des sciences, C.P. 6128, succ. Centre-Ville, Montréal (Québec), Canada, H3C 3J7

Authors' e-mail addresses: pierre-yves.cardon@umontreal.ca;

olivier.roques@etudiant.univ-lr.fr; antoine.caron@environnement.gouv.qc.ca; rosabal.maikel@uqam.ca; claude.fortin@ete.inrs.ca 


\begin{abstract}
Our knowledge of the processes leading to the bioaccumulation of rare earth elements (REE) in aquatic biota is limited. As the contamination of freshwater ecosystems by anthropogenic REE have recently been reported, it becomes increasingly urgent to understand how these metals are transferred to freshwater organisms in order to develop appropriate guidelines. We exposed rainbow trout (Oncorhynchus mykiss) to an REE, yttrium (Y), to either a range of Y-contaminated prey (Daphnia magna) or a range of Ycontaminated water. For the feeding experiment, the relationship between the $\mathrm{Y}$ assimilation by $O$. mykiss and the Y subcellular fractionation in D. magna was evaluated. Assimilation efficiency of $\mathrm{Y}$ by $O$. mykiss was low, ranging from 0.8 to $3 \%$. These values were close to the proportion of Y accumulated in D. magna cytosol, $0.6-2 \%$, a theoretical trophically available fraction. Moreover, under our laboratory conditions, water appeared as a poor source of $\mathrm{Y}$ transfer to $O$. mykiss. Regardless of the source of contamination, a similar pattern of $\mathrm{Y}$ bioaccumulation among O. mykiss tissues was revealed: muscles $<$ liver $<$ gills $<$ intestine. We conclude that the trophic transfer potential of $\mathrm{Y}$ is low and the evaluation of $\mathrm{Y}$ burden in prey cytosol appears to be a relevant predictor of $\mathrm{Y}$ assimilation by their consumers.
\end{abstract}

Keywords: yttrium; subcellular partitioning; trophic transfer; metal; fish; rare earth elements

\title{
Capsule:
}

The trophic transfer potential of the rare earth element yttrium is low and the evaluation of $\mathrm{Y}$ burden in prey cytosol is a relevant predictor of $\mathrm{Y}$ assimilation by their consumers. 


\section{Introduction}

Rare earth elements (REE) find applications in the electrification of transport, in wind energy production, in medical imaging, in agriculture and in many new technologies (Gwenzi et al., 2018). In recent years, the environmental risks associated with REE have received increasing attention (González et al., 2015). Indeed, as a direct consequence of our high consumption of REE (Alonso et al., 2012), cases of natural freshwater aquatic ecosystems contaminated by these metals as a result of human activity have been reported (Kulaksız and Bau, 2011; Ma et al., 2018). These elements are often divided according to their mass into two groups, the light (LREE) and the heavy (HREE) REE, with the heavier ones considered by some authors as most toxic (González et al., 2015). Among the HREE, yttrium (Y) is the most abundant in the earth's crust but studies on $\mathrm{Y}$ behaviour and toxicity in freshwater ecosystems are scarce. It is therefore urgent to improve our knowledge of the risk associated with $\mathrm{Y}$ and HREE in general. Understanding how $\mathrm{Y}$ is internalised into freshwater organisms commonly consumed by humans, such as fish, is particularly important for the future assessment of the environmental and health risks of HREE.

Fish acquire metals through two uptake routes: water and food. Although water is often a significant source of metal assimilation (Ahlf et al., 2009), it is well established that food can also be an important source for some metals, such as selenium (Økelsrud et al., 2016), cadmium (Croteau et al., 2005), and methylmercury (Hall et al., 1997).

The gills and the gastrointestinal tract are the main sites of metal uptake in fish. Waterborne metal uptake in particular occurs largely across the gills. From this entry 
point, metals can then be biodistributed in different organs. Models, such as the gill site interaction model (GSIM), the free ion activity model (FIAM) and the biotic ligand model (BLM), involving these different factors, have been developed for assessing this uptake (Pagenkopf, 1983; Campbell, 1995; Di Toro et al., 2001) .

Metals may also enter the body through diet. If, for organic contaminants, the lipophilicity of the contaminant seems to be a key parameter (Arnot and Gobas, 2006), for inorganic contaminants such as metals no consensus as to the physical or chemical factor controlling trophic transfer has yet been found. However, analysis of the subcellular fractionation of the metal considered in the prey could give an indication of its assimilative capacity by the predator. Indeed, several studies observed a correlation between the proportion of metal accumulated in the most soluble components of prey cells (e.g. cytosolic proteins, microsomes, etc.) and the assimilation efficiency of this metal by the predator (Reinfelder et al., 1994; Dubois and Hare, 2009a; Wallace and Luoma, 2003). Thus, it could be possible to predict the trophic transfer potential of a metal from the analysis of its subcellular fractionation in prey.

In a recent study (Cardon et al., 2019), we established that more than $75 \%$ of $\mathrm{Y}$ is accumulated in insoluble fractions (i.e. cellular debris and $\mathrm{NaOH}$-resistant fraction) in Daphnia magna and Chironomus riparius which are typical trout prey. This $\mathrm{Y}$ accumulation in putative trophically unavailable fractions suggests a weak potential of trophic transfer for this metal. In addition, measurements of REE along trophic webs of temperate (Amyot et al., 2017) and arctic (MacMillan et al., 2017) freshwater ecosystems, demonstrate a biodilution of these metals with increasing trophic levels rather than a biomagnification. 
This paper aims to: 1) compare the relative importance of diet and water as uptake pathways for $\mathrm{Y}$ in fish; 2) study $\mathrm{Y}$ biodistribution; 3) establish the potential for trophic transfer for $\mathrm{Y}$ under controlled laboratory conditions; and 4) assess whether the analysis of Y subcellular fractionation in prey can be used to predict its trophic transfer. For this purpose, feeding experiments on the rainbow trout (Oncorhynchus mykiss), a freshwater fish commonly used in ecotoxicology and consumed by humans, were performed with a range of Y-laden D. magna as prey. In parallel, exposures of O. mykiss to Y-spiked water, free of food, were set up to compare the potential of Y transfer from water and from food. Finally, Y partitioning between different tissues of O. mykiss (i.e., muscles, liver, intestine and gills) was assessed in each experiment to determine the main organs where this metal accumulates.

\section{Materials and methods}

\section{Sources of animals}

Daphnia magna was cultured at the Centre d'expertise en analyse environnementale du Québec (CEAEQ, Quebec City, QC, Canada). Oncorhynchus mykiss individuals were purchased from the Pisciculture des Arpents Verts (Sainte-Edwidge, QC, Canada) and were acclimated to laboratory conditions for at least 3 weeks prior to their use. Exposure solutions were spiked using dilutions of a standard $\mathrm{Y}$ solution $(10,000 \mu \mathrm{g} / \mathrm{ml} \mathrm{Y}$ in $3 \%$

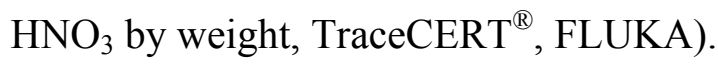




\section{Accumulation of Yttrium from water}

Fish $(1.6 \pm 0.2 \mathrm{~g})$ were exposed to $\mathrm{Y}$-enriched dechlorinated tap water for $5 \mathrm{~d}$ in groups of seven individuals in $20 \mathrm{~L}$ aerated aquaria lined with polypropylene (PP) bags (one aquarium for each concentration level; $\mathrm{pH} 7.8,63 \mathrm{mg} \mathrm{CaCO}_{3} \mathrm{~L}^{-1}$, $\left.15 \pm 0.2{ }^{\circ} \mathrm{C}\right)$. Chemical characteristics of the tap water are given in Supporting Information (SI; Table S1). Fish were not fed $24 \mathrm{~h}$ before and during the exposure period. Five $\mathrm{Y}$ nominal exposure levels plus the control $\left(0 \mu \mathrm{g} \mathrm{Y} \mathrm{L^{-1 } )}\right.$ were tested: 52, 86, 144, 240 and $400 \mu \mathrm{g} \mathrm{Y} \mathrm{L}{ }^{-1}$. In addition, dissolved Y concentrations were measured every day during the exposure period (SI, Table S2). Yttrium exposure conditions over the bioconcentration assay are given in SI, Table S2. We observed a decrease over time of $\mathrm{Y}$ dissolved concentrations, likely due in part to $\mathrm{Y}$ adsorption to exposure vessels and to Y precipitation (subsequent analysis of tap water used revealed the presence of sufficiently high concentrations of phosphate to suggest precipitation).

\section{Trophic transfer experiment}

\section{Exposure of prey to $Y$}

D. magna neonates $(<24 \mathrm{~h})$ were reared for $7 \mathrm{~d}$ in $15 \mathrm{~L}$ aquaria lined with a PP bag filled with dechlorinated tap water (300 individuals per aquarium). They were then transferred for $24 \mathrm{~h}$ to another set of aquaria also lined with a PP bag but filled this time with $15 \mathrm{~L}$ of reconstituted water $\left(\mathrm{pH} 7.8 \pm 0.1,89 \pm 2 \mathrm{mg} \mathrm{CaCO}_{3} \mathrm{~L}^{-1}, 21 \pm 1{ }^{\circ} \mathrm{C}\right)$ spiked with Y. After this exposure period, Y-spiked D. magna were transferred for 5 min in a $1 \mathrm{mM}$ EDTA 
solution to remove $\mathrm{Y}$ adsorbed to their body surface, rinsed with Milli-Q water, before being dried on Kimwipes ${ }^{\circledR}$ and stored in a 50 -mL tube at $-80{ }^{\circ} \mathrm{C}$.

To obtain a range of Y-laden D. magna, we prepared five batches of D. magna exposed to one of the five following nominal concentrations all of which were subsequently analytically determined: 0 (control), 86, 144, 240 and $400 \mu \mathrm{g} \mathrm{Y} \mathrm{L}^{-1}$. When the mass needed for each level of the feeding experiment was reached, Y-laden daphnids were pooled into groups of $20 \pm 4 \mathrm{mg}$ of wet weight (ww), corresponding to the daily meal for one fish, and stored at $-80{ }^{\circ} \mathrm{C}$ into 96 -wells microplate (Greiner Bio-one) pre-soaked in $\mathrm{HNO}_{3}(15 \%, \mathrm{v} / \mathrm{v}$, Optima grade, Fisher Scientific) and rinsed in Milli-Q water, each well containing one group.

\section{Subcellular fractionation of D. magna}

Five samples of about 80-100 mg of D. magna of each Y exposure concentration were subjected to the subcellular fractionation procedure, based on Wallace et al. (2003) and customized for D. magna (Cardon et al., 2018) (Fig.1). Each D. magna sample was suspended in Tris-HCl (25 mM; OmniPur) sucrose buffer (250 mM; pH 7.4; Sigma Aldrich) at a ratio of 1:4 (weight [mg]: buffer volume $[\mu \mathrm{L}])$. Then, the suspended sample was ground with a Potter-Elvehjem pestle at $570 \mathrm{rpm} 2 \mathrm{~s}$ repeated 10 times, with a 30-s interval of rest between each homogenization period. The resulting homogenate was centrifuged at $800 \mathrm{~g}$ for $15 \mathrm{~min}$. The supernatant was collected and the pellet was resuspended in Tris-sucrose buffer at a ratio of 1:4 before disruption with an ultrasonic probe (Branson 250, with a $4.8 \mathrm{~mm}$ diameter microtip probe), at a power of $22 \mathrm{~W}$, with pulses at $0.2 \mathrm{~s} \mathrm{~s}^{-1}(20 \%)$ for $1 \mathrm{~min}$. The resulting homogenate was pooled and mixed using a vortex with the first supernatant for a final ratio between sample and buffer of 
1:8. Subsequently homogenates were separated into five partially validated fractions by differential centrifugation as described in Figure 1: P2) organelles (mitochondrial membranes, lysosomes and microsomes); P3) Heat-Denaturated Proteins (HDP) including enzymes; S3) Heat-Stable Proteins (HSP) including metallothioneins; S4) Debris (nuclei, cellular membrane and debris); and $\mathrm{P} 4) \mathrm{NaOH}-$-resistant fraction (granules and potentially the daphnid chitinous exoskeleton).

Centrifugations $(<25,000 \mathrm{~g})$ were performed using an IEC Micromax centrifuge (Thermo IEC) whereas a WX ULTRA 100 centrifuge (Sorval, Ultra Thermo Scientific) equipped with a F50L-24 X1.5 rotor (Fisher Scientific) was used for ultracentrifugation $(\geq 25,000 \mathrm{~g})$.

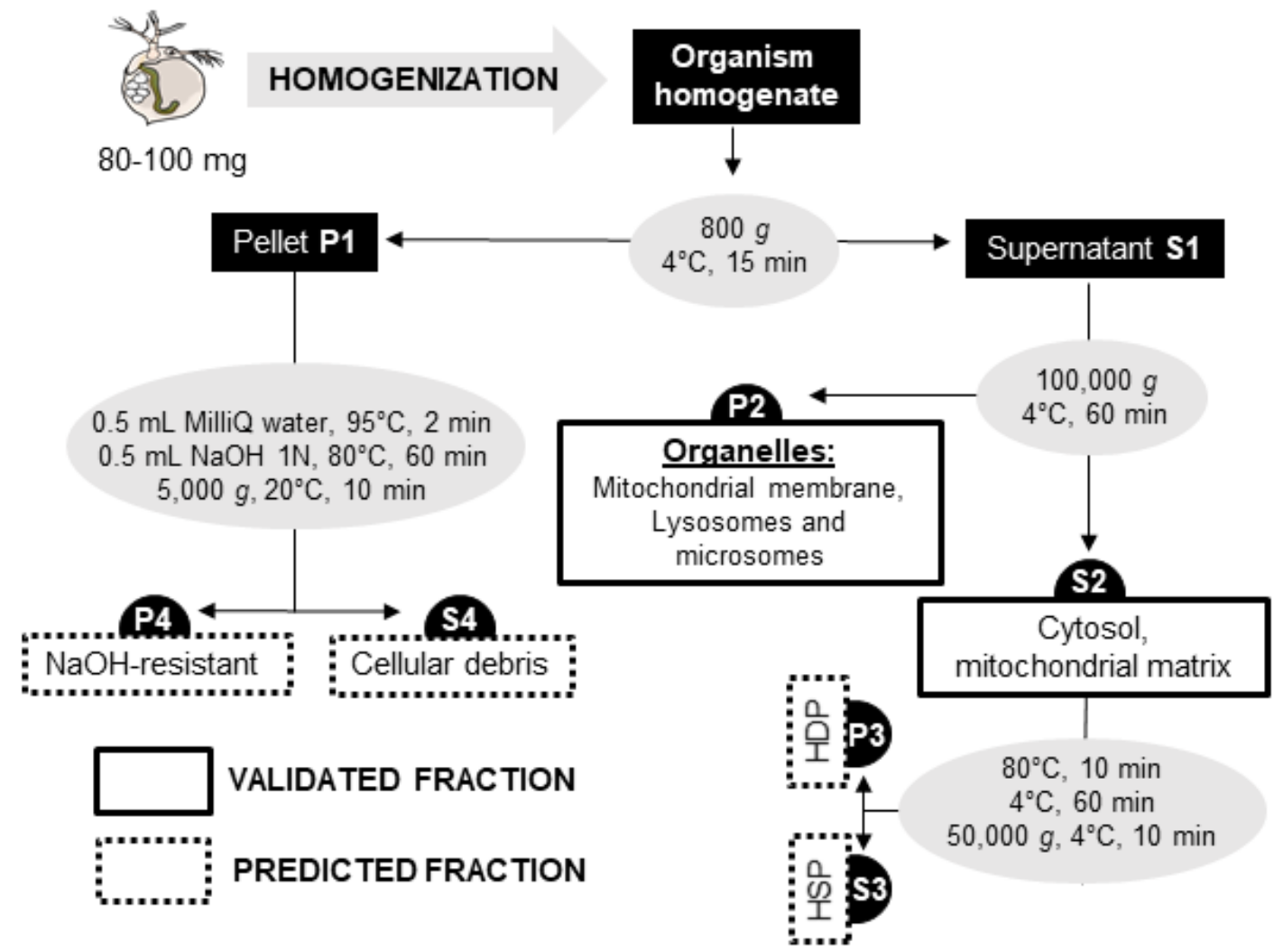

Figure 1 - Subcellular fractionation protocol customized for D. magna as developed in Cardon et al. (2018). P: Pellet; S: Surpernatant; HDP: Heat Denatured Proteins; HSP: 
Heat Stable Proteins. Validated fractions are those that are derived from our enzymatic validation protocol (see text); predicted fractions are those that cannot be validated enzymatically and are therefore predicted from the literature.

\section{Exposure of O. mykiss to Y-laden daphnids}

Fish $(0.93 \pm 0.14 \mathrm{~g})$ were exposed individually in 1-L aerated glass beakers filled with dechlorinated tap water $\left(\mathrm{pH} 7.8,63 \mathrm{mg} \mathrm{CaCO}_{3} \mathrm{~L}^{-1}, 15 \pm 0.2{ }^{\circ} \mathrm{C}\right)$. Seven individuals were used for each Y exposure levels of daphnids. Prior to the experiment, fish were fed with control daphnids for $10 \mathrm{~d}$. Then, for $5 \mathrm{~d}$, fish were fed $2 \%$ of their body weight (wet weight of prey to wet weight of fish) daily with their corresponding Y-laden daphnids. All daphnid pellets were consumed within seconds of being added. Every day, faeces were removed with a 50-mL glass pipette after a 1-h feeding period to avoid subsequent $\mathrm{Y}$ release to the medium. In addition, to monitor potential Y efflux from fish (from urine and feces), the water of each experimental chamber was sampled using a 20-mL PP syringe, then filtered through a $0.45 \mu \mathrm{m}$ polyethersulfone syringe filter to measure dissolved Y concentrations daily. Chemical characteristics of the water medium at the beginning of the trophic transfer experiment and $\mathrm{Y}$ exposure condition over the trophic transfer assay are given respectively in SI, Table S1 and Table S3.

\section{Fish treatment and storage at the end of the experiments}

Coefficients of variation of fish average wet weight between each exposure level did not exceed 5\%. At the end of the experiment, fish were depurated for $24 \mathrm{~h}$. They were then euthanized with clove extract, rinsed with EDTA $(1 \mathrm{mM})$, then with Milli-Q water, dried with Kimwipes ${ }^{\circledR}$, and finally weighed and measured for their fork length. Their gills, 
intestine, liver, muscle tissues and remaining body parts were collected with a surgical razor blade. Tissues were put in $1.5 \mathrm{~mL}$ pre-weighed and acid-washed PP microcentrifuge tube, and remaining body parts were collected in $50 \mathrm{~mL}$ tube. They were then weighed, freeze dried, weighed again and stored at $-80{ }^{\circ} \mathrm{C}$ until $\mathrm{Y}$ analyses.

\section{Yttrium measurements and quality control}

All labware was soaked in $\mathrm{HNO}_{3}(15 \%$, v/v, Optima grade, Fisher Scientific) and rinsed seven times in Milli-Q water before use, to minimize $\mathrm{Y}$ accidental contamination. Centrifuged pellet fractions resulting from the fractionation of D. magna $(\mathrm{NaOH}-$ resistant fraction, organelles and HDP), aliquots sampled as homogenate and O. mykiss tissues were freeze-dried for $24 \mathrm{~h}$, weighed and stored at $-80{ }^{\circ} \mathrm{C}$. Every subcellular fraction and O. mykiss tissues were digested at $65{ }^{\circ} \mathrm{C}$ in $500 \mu \mathrm{L}$ of $\mathrm{HNO}_{3}(70 \%$, v/v) whereas O. mykiss remaining parts were subjected to the same procedure but in $4 \mathrm{~mL}$ of $\mathrm{HNO}_{3}$. Then, $9.5 \mathrm{~mL}$ and $45 \mathrm{~mL}$ of Milli-Q water were added in the digestates of D. magna fractions and O. mykiss tissues, respectively.

Concentrations of $\mathrm{Y}$ in water and in organism fractions and tissues were measured with an inductively coupled plasma-mass spectrometer (ICP-MS; Thermo Elemental X Series). To ensure quality of these measurements, samples of similar weight of a certified standard reference material, BCR 668 (mussel tissue, Institute for Reference Materials and Measurements) underwent the same digestion procedure and analysis. Mean ( \pm SD) recoveries of BCR 668 reference samples $(n=10)$ were within the range of certified values for Y $(90.0 \pm 0.1 \%)$. To verify metal recovery following subcellular fractionation, $40-\mu \mathrm{L}$ subsamples of tissue homogenate were analyzed. Recovery was expressed as the ratio of the sum of the $\mathrm{Y}$ burden in the five fractions divided by the total homogenate $\mathrm{Y}$ 
burden in D. magna, multiplied by 100 . Mean $( \pm \mathrm{SD})$ recovery values of Y was $99 \pm 4 \%$ $(n=25)$.

\section{Calculation and statistical analyses}

Yttrium concentrations in O. mykiss tissues and D. magna homogenates were expressed by wet weight ( $\left.\mathrm{mg} \mathrm{kg}^{-1} \mathrm{ww}\right)$. Yttrium burden in a given subcellular fraction of D. magna was divided by the sum of $\mathrm{Y}$ burden in all fractions and multiplied by 100 to assess the relative contribution of each subcellular fraction to the total $\mathrm{Y}$ burden in terms of percentages $(\%)$.

Assimilation efficiency (AE) was calculated according to Lapointe et al. (2009) as follows:

$$
\mathrm{AE}=\left[\frac{\mathrm{M}_{\text {O.mykiss }}-\mathrm{M}_{\text {control }}}{\mathrm{M}_{\text {D. magna }}}\right] \times 100
$$

where $\mathrm{M}_{O \text {. mykiss }}$ is the $\mathrm{Y}$ burden in fish fed $\mathrm{Y}$-laden daphnids, $\mathrm{M}_{\text {control }}$ is the average $\mathrm{Y}$ burden in fish fed uncontaminated daphnids and $\mathrm{M}_{D \text {. magna }}$ represents the total amount of $\mathrm{Y}$ provided to fish from Y-laden D. magna. This equation for $\mathrm{AE}$ defines the bioaccumulation factor. It roughly estimates $\mathrm{AE}$ if it is assumed that the prey is consumed and that physiological losses of $\mathrm{Y}$ and growth of the test subject during the exposure and depuration phases are inconsequential. In our study, all food pellets given to the fish were eaten within minutes. Further, we assumed that fish growth during the experiment was minimal. Also, efflux rates of $\mathrm{Y}$ from fish to water were also considered low, since aqueous Y levels remained relatively low during the experiment (Table S3).

Data are expressed as mean \pm standard deviation (SD). Significant differences were 
tested with a one-way analysis of variance (ANOVA), followed by Tukey pairwise comparison test $(p<0.05)$. Linear regression analyses were performed to study the relationship between $\mathrm{Y}$ accumulation according to $\mathrm{Y}$ exposure level. The assumptions of normality and homoscedasticity were verified by Shapiro-Wilk's and Levene's tests, respectively. When these assumptions were not met, a natural log transformation was successfully applied on the data. Statistical analyses were performed using R software version 3.4.4.

\section{Results and Discussion}

There are few studies on fish biodistribution and subcellular fractionation of group A metals (Kinraide, 2009; Nieboer and Richardson, 1980), including REE. Therefore, in the discussion that follows, our results on $\mathrm{Y}$ in O. mykiss will be essentially compared to metals belonging to the intermediate group such as $\mathrm{Cd}$, or group $\mathrm{B}$ such as $\mathrm{Cu}$, for which more data on accumulation, biodistribution and subcellular fractionation in fish are available.

\section{Bioaccumulation and distribution of $\mathrm{Y}$ in $O$. mykiss tissue depending on the exposure source}

We compared the bioaccumulation of $Y$ from water and diet in different trout organs. In the water-only exposures, when excluding the maximal exposure level, the intestine presented the top values of bioaccumulated Y (Fig. 2A). However, unlike other tissues, no relationship was found between the $\mathrm{Y}$ content in the intestine and the exposure concentration (Fig. 2A). In contrast, a strong positive correlation $\left(\mathrm{R}^{2}=0.7, \mathrm{p}=0.003\right)$ 
was observed between Y concentration in gills and water exposure level (SI, Fig. S1A). At the maximal exposure of $180 \mu \mathrm{g} \mathrm{Y} \mathrm{L} \mathrm{L}^{-1}$, the $\mathrm{Y}$ concentrations in the gills and the intestine were statistically similar. Hence, the $\mathrm{Y}$ concentration of the gills increased with aqueous $\mathrm{Y}$ and at the highest exposure attained a concentration equal to the concentration of the intestine (Fig. 2A). At this maximal exposure, concentrations of $\mathrm{Y}$ in the liver and in the remaining body parts were more than ten times lower than in the gills and the intestine. In general, in the water exposure test, the concentrations of $Y$ in the liver and in the remaining parts of the fish body were similar and at an intermediate level between the values measured in the muscles and gills. For clarity, the highest concentration in the gill occurred at the highest exposure.

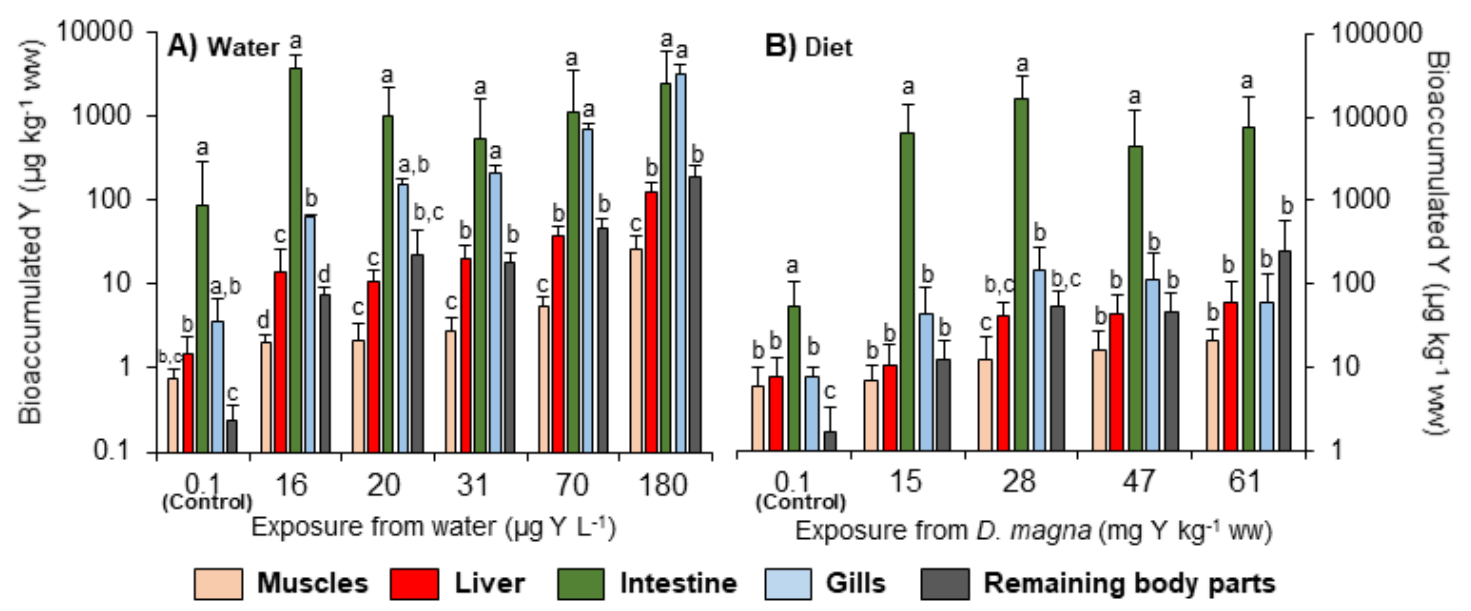

Figure 2 - Bioaccumulation of $\mathrm{Y}$ (Mean $\left.\pm \mathrm{SD} ; \mu \mathrm{gg}^{-1} \mathrm{ww} ; \mathrm{n}=5-7\right)$ in different tissues of O. mykiss following two types of exposures A) from water $\left(\mu \mathrm{g} \mathrm{Y} \mathrm{L}^{-1}\right)$ or $\left.\mathbf{B}\right)$ from diet (mg Y kg ${ }^{-1} \mathrm{ww}$ of daphnid), over an exposure range. Different letters indicate a significant difference of accumulation among the different tissues of O. mykiss for a given exposure level (ANOVA, followed by Tukey pairwise comparison test, $p<0.05$ ). The lowest exposure level for both experiments represents the control. Exposure 
conditions over these tests, especially $\mathrm{Y}$ dissolved concentrations, are given in SI, Tables S2 and S3.

When exposing fish to $\mathrm{Y}$ through diet, concentrations of $\mathrm{Y}$ in the intestine were 7 to 1370 times higher than those in all other tissues (Fig. 2B). In contrast, no significant differences were measured between $\mathrm{Y}$ concentrations in the liver (min-max: 11-61 $\mu \mathrm{g} \mathrm{Y}$ $\left.\mathrm{kg}^{-1} \mathrm{ww}\right)$, in the remaining parts of the fish body (12-243 $\left.\mu \mathrm{g} \mathrm{Y} \mathrm{kg}{ }^{-1} \mathrm{ww}\right)$ and in the gills (44-143 $\mu \mathrm{g} \mathrm{Y} \mathrm{kg}^{-1}$ ww) (Fig. 2B), when excluding the control. Furthermore, unlike the water exposure trial, no relationship between $\mathrm{Y}$ exposure concentrations in gills and the level of Y in D. magna (SI, Fig. S1B) was observed.

Regardless of the source of exposure, the Y content determined in muscle tissues was significantly lower than in other tissues with average values between 1 and $25 \mu \mathrm{g} \mathrm{Y} \mathrm{kg}{ }^{-1}$ ww (Fig. 2). In addition, for both exposure trials, the burden of $\mathrm{Y}$ in the intestine was, on average, higher than the whole fish less the intestine. Overall, a similar pattern of Y partitioning between O. mykiss tissues was observed for both exposure routes, with the following sequence of Y concentrations in body parts: muscles $<$ liver $<$ gills $<$ intestine.

Other field studies have reported low $\mathrm{Y}$ concentrations in muscles compared to other tissues. In ten freshwater fish species from a reservoir in the state of Washington (USA), muscles had lower REE concentrations (on average at least three times lower for $\mathrm{Y}$ ) than in the whole body and carcass (Mayfield and Fairbrother, 2015). Moreover, significantly larger differences were measured in three fish species from Canadian temperate lakes for which whole-body REE concentrations were on average at least 40 times higher than muscle concentrations (Amyot et al., 2017). In general, metal concentrations in fish 
muscles have been reported to be lower in most cases than in other organs (Subotic et al., 2014).

Our results further suggest that gills are among the main tissues for $\mathrm{Y}$ accumulation in fish. Since gills were thoroughly rinsed with EDTA solution and water, it is unlikely that these high levels are caused by external particles (from food or feces) trapped in gills. This importance of gills as an REE accumulation site has previously been reported (Sun et al., 1996; Tu et al., 1994). Analysis of Y subcellular fractionation in O. mykiss gills could be another step to investigate REE accumulation in this organ. Preferential accumulation of $\mathrm{Zn}$ in cellular debris fractions (including cell membranes) of $O$. mykiss gills cells has already been reported (Sappal et al., 2009). Hence, we hypothesize that Y will be mainly accumulated in cellular debris fractions of gills cells as well.

The relatively high concentrations of $\mathrm{Y}$ in the gills may have detrimental effects on fish health. REE are known to be antagonists of $\mathrm{Ca}$ uptake; lanthanum for example, is commonly used as a $\mathrm{Ca}^{2+}$ channel blocker in studies on metal uptake by gills (Hogstrand et al., 1996). Indeed, gills are considered as the first route of Ca uptake by freshwater fish (Marshall, 2002), Ca uptake by the intestine being considered as secondary (Flik et al., 1996). Hence, the accumulation of $\mathrm{Y}$ in the gills of O. mykiss could lead to Ca deficiency in this organism. The assimilation of essential metals, such as $\mathrm{Zn}$, which can be taken up through $\mathrm{Ca}^{2+}$ channels (Hogstrand et al., 1996) could also be limited due to the presence of $\mathrm{Y}$. Therefore, we suspect that $\mathrm{Y}$ could have adverse effects on the ionoregulation within O. mykiss. Like La, we suspect that $\mathrm{Y}$ blocks $\mathrm{Ca}$ and $\mathrm{Zn}$ internalization through the apical gill membrane but does not enter the gill cell cytosol (Perry and Flik, 1988). 
The observed preferential accumulation of $Y$ in internal organs like the intestine, seems in agreement with the literature. For instance, laboratory studies on the biodistribution of seven REEs including Y have reported the following concentration pattern in Cyprino carpio : muscles $<$ skeleton $<$ gills $<$ internal organs (Sun et al., 1996; Tu et al., 1994). Note that organs included in internal organs in these two studies are not defined. This pattern was also reported in O. mykiss for other metals, including $\mathrm{Cd}, \mathrm{Cu}$ and $\mathrm{Se}$, following an exposure to a diet enriched with these metals (Handy, 1992; Misra et al., 2012). For $\mathrm{Se}$ and $\mathrm{Cu}$ however, liver showed higher concentration than gills. Similarly, the importance of the liver (compared to muscle) as a site of REE accumulation in vertebrates has already been reported in Arctic ecosystems (MacMillan et al., 2017). Furthermore, in 28-d exposures to similar Y concentrations, the $\mathrm{Y}$ concentration in the liver of O. mykiss was about ten times higher than the one we measured here after 5 days (Cardon et al., 2019). This suggests that $\mathrm{Y}$ concentration in O. mykiss tests may not have reached a steady state at the end of our tests. Therefore, we can assume that liver could be a more important organ of $\mathrm{Y}$ accumulation for fish in the field than what we evaluated. Another trial involving both water and diet as exposure routes and a longer period of exposure to Y, could be a way to test this hypothesis.

\section{Range of bioaccumulation and subcellular fractionation in daphnids}

A strong linear relationship $\left(\mathrm{R}^{2}=0.95, p=3.0 \cdot 10^{-16}\right)$ was observed between $\mathrm{Y}$ bioaccumulation by D. magna and the $\mathrm{Y}$ exposure level (Fig. 3A). The levels of $\mathrm{Y}$ accumulation by D. magna ranged from $0.05 \pm 0.03$ to $62 \pm 7 \mathrm{mg} \mathrm{Y} \mathrm{kg}^{-1}$ ww. At the subcellular level, Y was mainly found in the NaOH-resistant fraction with, on average, 
$81 \pm 11 \%$ of the total Y (Fig. 3B). Organelles contained $11 \pm 6 \%$ of the total Y, while the remainder $(<10 \%)$ was divided between the other fractions (debris, HDP and HSP).
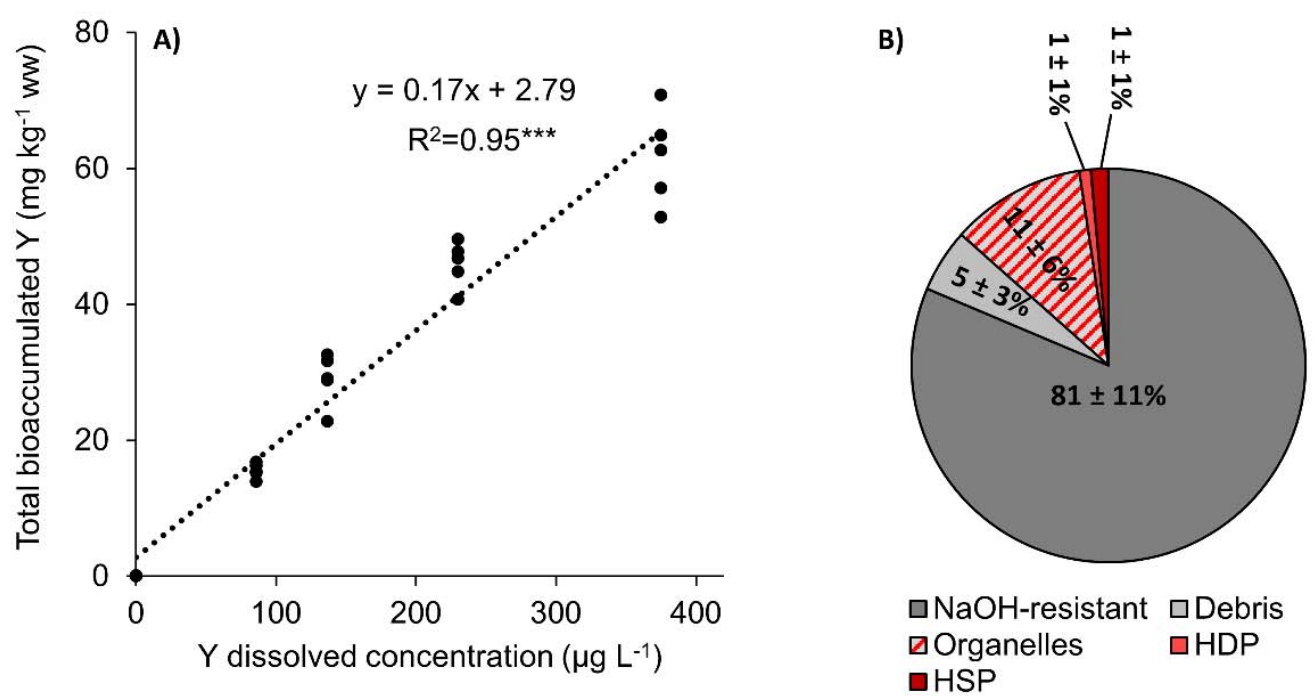

Figure 3 - Characterization of Y accumulation in daphnids. A) Relationship between the Y exposure level and the total of $\mathrm{Y}$ bioaccumulated by D. magna $\left({\mathrm{mg} \mathrm{Y} \mathrm{g}^{-1}}^{\mathrm{ww}} \mathrm{n}=5\right)$; B) Average percentage of $\mathrm{Y}$ for all exposure levels (mean $\pm \mathrm{SD} ; \% ; \mathrm{n}=5$ ) in each subcellular fraction of Y-exposed D. magna.

Such high values of $\mathrm{Y}$ bioaccumulated by D. magna (Fig. 3A) have previously been reported in laboratory studies (Cardon et al., 2018; Yang et al., 1999), but are at least 1000 times higher than those reported in zooplankton from the field (Amyot et al., 2017; MacMillan et al., 2017). Yttrium subcellular fractionation reported here is similar to the Y subcellular fractionation in D. magna assessed with a longer exposure period of $7 \mathrm{~d}$ (Cardon, 2018). 
According to several authors (Dubois and Hare, 2009a; Wallace and Luoma, 2003), only the part of metal bound to the putative trophically available fraction in the prey cells, the so-called trophically available metal (TAM), will be transferred to their consumer. Therefore, the trophic transfer potential of a metal could be assessed based on its subcellular fractionation in the prey. Our results suggest a weak potential of $Y$ trophic transfer from D. magna to its predator. Indeed, by considering only $\mathrm{Y}$ found in the cytosol (HDP and HSP) of D. magna as the TAM (Wallace and Lopez, 1996), less than $3 \%$ of Y in this organism would be theoretically trophically available. Even if we include $\mathrm{Y}$ associated to organelles in the TAM pool, as recommended by several authors (Dubois and Hare, 2009a; Wallace and Luoma, 2003), this transfer potential remains under 15\%. In contrast, the proportion of TAM (including organelles), reported for $\mathrm{Ni}, \mathrm{Tl}$ and $\mathrm{Zn}$ in D. magna exceeded 40\% (Lapointe et al., 2009; Wang and Guan, 2010).

Note that daphnids used as prey in this experiment were contaminated through exposure to $\mathrm{Y}$-enriched water and not $\mathrm{Y}$-enriched diet. It is possible that subcellular fractionation in Daphnia and subsequent trophic transfer to trout could be different if an Y-enriched diet would have been used.

\section{Relationship between assimilation efficiency and trophically available metal}

Percentages of $\mathrm{Y}$ found in the cytosol of D. magna appeared to be very close to the AE in O. mykiss. Over the trophic transfer trial, percentages of $\mathrm{Y}$ in D. magna cytosol ranged from 0.63 to $1.6 \%$ while $\mathrm{AE}$ ranged from 0.80 to $3.0 \%$ (Fig. 4). When adding organelles, the TAM fraction increased significantly (range: 7.8 to $14 \%$ ) and departed from the measured AE (Fig. 4). Moreover, the spread of \% of potentially available $\mathrm{Y}$ increased with the addition of Y recovered in D. magna organelles to the pool of TAM. These 
results suggest that the $\mathrm{Y}$ in $D$. magna cytosol was trophically available while the $\mathrm{Y}$ associated to organelles was not. In contrast, many authors have concluded that at least a part of the metal from the organelles fraction was available: for instance, $\mathrm{Cd}$ transferred from Potamocorbula amurensis to Palaemon macrodatylus (Wallace and Luoma, 2003) and from Gammarus lawrencianus to Palaemontes pugio (Seebaugh et al., 2006); Cd, $\mathrm{Zn}, \mathrm{Ni}, \mathrm{Tl}$ and $\mathrm{Se}$ transferred from Chironomus riparius to Sialis velata (Dubois and Hare, 2009a, 2009b; Dumas and Hare, 2008). Even NaOH-resistant fraction was considered as potentially available in some studies (Cheung and Wang, 2005; Rainbow et al., 2007).

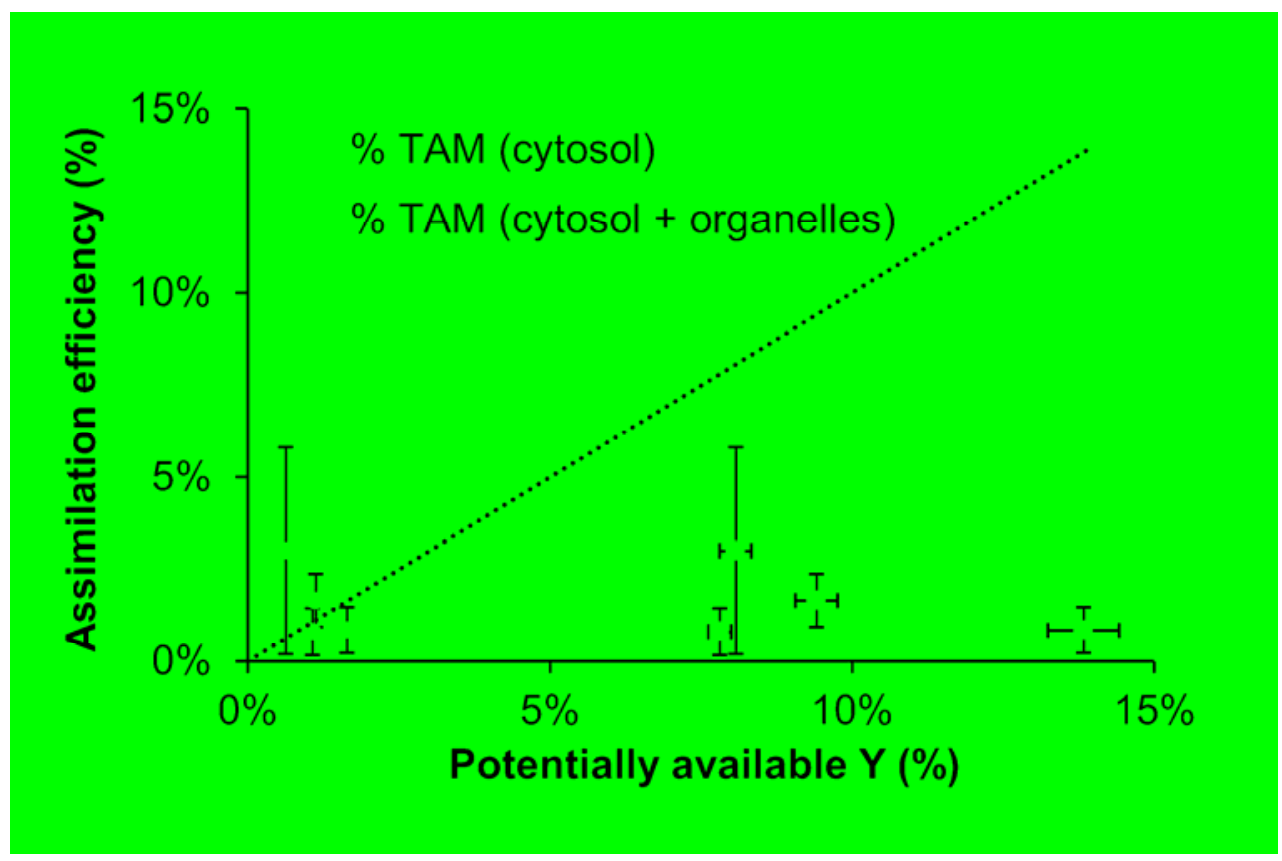

Figure 4 - Relationship between assimilation efficiency of dietary $\mathrm{Y}$ in O. mykiss and the proportion of Y assumed to be trophically available (TAM) in D. magna with or without the inclusion of organelles in TAM (means $\mathrm{SD}, \mathrm{n}=5-7$ ). The dashed line illustrates a 1:1 relationship. 
Different prey species can have similar proportions of a theoretically available metal in their cells but still have large differences of AE for their consumers (Pouil et al., 2016). In fact, it is usually accepted that subcellular components included in the TAM pool differs depending on the prey and the predator (Rainbow et al., 2011). For instance, for a given prey, the assimilation of metal-containing fractions by a predator will depend on the strength of its digestive processes To get insight on the relative strength of this digestive process for O. mykiss, we can compare metal $\mathrm{AE}$ of several fish with those of invertebrate predators fed with the same prey. Three marine fish, Lutjanus argentimaculatus, Penophthalmus cantonensis and Ambassis urotaenia, assimilated 6$33 \%$ and $5-46 \%$ of respectively $\mathrm{Cd}$ and $\mathrm{Zn}$ from copepod and clam prey (Xu and Wang, 2002) while two invertebrates, Palaemontes varians and Hinia reticulata, assimilated on average more than $60 \%$ of the same metals from the same prey (Rainbow and Smith, 2010). Similarly, Sialis velata, an invertebrate predator, assimilated more than $70 \%$ of $\mathrm{Cd}, \mathrm{Ni}$ and $\mathrm{Tl}$ from two invertebrate prey (Dubois and Hare, 2009b; Dumas and Hare, 2008), while several fish, including O. mykiss, fed with similar metal-laden prey, assimilated less than $10 \%$ of these metals (Béchard et al., 2008; Lapointe et al., 2009; Ng and Wood, 2008; Steen Redeker et al., 2007a). Finally, the barnacle, Balanus amphitrite, assimilated more than $63 \%$ of $\mathrm{Cr}$ from zooplankton prey (Wang et al., 1999) versus less than $12 \%$ for fish fed with similar prey (Ni et al., 2000). All these examples could suggest a "softer" digestive process for some fish including trout.

Beyond the type of digestive processes, the similar AE and TAM values we measured for Y could be simply the result of the low AE of nonessential metal for fish. Some studies comparing trophic transfer of essential metals such as $\mathrm{Zn}$ or Se from a variety of prey to 
fish have reported close values between AE and metal bound to prey cytosol (Zhang and Wang, 2006). Nonetheless so far, except for $\mathrm{Hg}$, most studies on the relationship between nonessential metal trophic transfer to fish and the percentage of this metal theoretically available in their prey observed an $\mathrm{AE}$ far lower than predicted and hence departed from the expected 1:1 line (representing a perfect correlation) with TAM. Indeed, in the following examples, metals present in the cytosol of the prey represented more than $30 \%$ of the total bioaccumulated metal while AE of the fish fed with these prey did not exceed $10 \%$. It was the case for the trophic transfer of Cd from Tubifex tubifex to Cyprinus carpio (Steen Redeker et al., 2007b), for Cd from Lumbriculus lumbriculus to O. mykiss (Ng and Wood, 2008), for As from different prey (clam, copepod and fish) to Terapon jarbua (Zhang et al., 2011), for $\mathrm{Ag}$ from (Seabream, shrimp and ragworm) to Scophthalmus maximus (Pouil et al., 2015) and for Ni from D. magna or C. riparius to Pimephales promelas (Lapointe et al., 2009). Predictions of trophic transfer of nonessential metals to fish based on TAM analysis in its prey should thus be made with caution; indeed, the composition of the TAM fraction should not be assumed but should be directly validated through feeding experiments such as the ones presented here.

Overall, our results indicating low subcellular fractionation towards trophically available metal fractions are in agreement with the low $\mathrm{AE}$ for $\mathrm{Y}$. Hence, this work provides mechanistic evidence that could explain low REE levels reported in fish in the field studies. 


\section{Acknowledgments}

We would like to thank the technicians from the Centre d'expertise en analyse environnementale du Québec (Ministère de l'Environnement et de la Lutte contre les changements climatiques; MELCC) for their assistance in the breeding of organisms and in many chemical analyses. We also would like to thank the INRS-ETE technicians for their help in Y concentrations measurements. Finally, we would like to thank Nicolas Gruyer for his help in planning the laboratory work and for reviewing the document. This research was funded through the Natural Sciences and Engineering Research Council (NSERC) Discovery grant and an NSERC strategic grant (TRIVALENCE) to M. Amyot. This work was supported by the NSERC CREATE Mine of Knowledge network through a scholarship to P.-Y. Cardon. M. Amyot and C. Fortin are supported by the Canada

Research Chair Program. The lab ware used in experiments performed at the Quebec City CEAEQ were purchased and provided by the MELCC. 


\section{References}

Ahlf, W., Drost, W., Heise, S. 2009. Incorporation of metal bioavailability into regulatory frameworks - metal exposure in water and sediment. J. Soils Sediments 9, 411-419.

Alonso, E., Sherman, A.M., Wallington, T.J., Everson, M.P., Field, F.R., Roth, R., Kirchain, R.E., 2012. Evaluating rare earth element availability: a case with revolutionary demand from clean technologies. Environ. Sci. Technol. 46, 3406-14. https://doi.org/10.1021/es203518d

Amyot, M., Clayden, M.G., Macmillan, G.A., Perron, T., Arscott-Gauvin, A., 2017. Fate and trophic transfer of rare earth elements in temperate lake food webs. Environ. Sci. Technol. 51, 6009-6017. https://doi.org/10.1021/acs.est.7b00739

Arnot, J.A, Gobas, F.A., 2006. A review of bioconcentration factor (BCF) and bioaccumulation factor (BAF) assessments for organic chemicals in aquatic organisms. Environ. Rev. 14, 257-297. https://doi.org/10.1139/a06-005

Béchard, K.M., Gillis, P.L., Wood, C.M., 2008. Trophic transfer of Cd from larval chironomids (Chironomus riparius) exposed via sediment or waterborne routes, to zebrafish (Danio rerio): Tissue-specific and subcellular comparisons. Aquat. Toxicol. 90, 310-321. https://doi.org/10.1016/j.aquatox.2008.07.014

Campbell, P. G. C., 1995. Interactions between trace metals and aquatic organisms: A critique of the free-ion activity model. In Metal Speciation and Bioavailability in Aquatic Systems, Tessier, A.; Turner, D. R., Eds. John Wiley \& Sons: New York, NY, USA; pp 45-102. 
Cardon, P.-Y., Caron, A., Rosabal, M., Fortin, C., Amyot, M., 2018. Enzymatic validation of species-specific protocols for metal subcellular fractionation in freshwater animals. Limnol. Oceanogr. Methods 16, 537-555. https://doi.org/10.1002/lom3.10265

Cardon, P.-Y., Triffault-Bouchet, G., Caron, A., Rosabal, M., Fortin, C., \& Amyot, M. 2019. Toxicity and Subcellular Fractionation of Yttrium in Three Freshwater Organisms: Daphnia magna, Chironomus riparius, and Oncorhynchus mykiss. ACS Omega, 4, 13747-13755.

Cheung, M., Wang, W.-X., 2005. Influence of subcellular metal compartmentalization in different prey on the transfer of metals to a predatory gastropod. Mar. Ecol. Prog. Ser. 286, 155-166. https://doi.org/10.3354/meps286155

Croteau, A.M., Luoma, S.N., Stewart, A.R., Croteau, M., Survey, U.S.G., Road, M., Park, M., 2005. Trophic transfer of metals along freshwater food webs: Evidence of cadmium biomagnification in nature. Limnol. Oceanogr. 50, 1511-1519.

Di Toro, D. M.; Allen, H. E.; Bergman, H. L.; Meyer, J. S.; Paquin, P. R.; Santore, R. C., 2001. Biotic ligand model of the acute toxicity of metals. 1. Technical basis. Environ. Toxicol. Chem. 20, (10), 2383-2396.

Dubois, M., Hare, L., 2009a. Selenium assimilation and loss by an insect predator and its relationship to Se subcellular partitioning in two prey types. Environ. Pollut. 157, 772-777. https://doi.org/10.1016/j.envpol.2008.11.022

Dubois, M., Hare, L., 2009b. Subcellular distribution of cadmium in two aquatic invertebrates: Change over time and relationship to $\mathrm{Cd}$ assimilation and loss by a predatory insect. Environ. Sci. Technol. 43, 356-361. https://doi.org/10.1021/es801406r 
Dumas, J., Hare, L., 2008. The internal distribution of nickel and thallium in two freshwater invertebrates and its relevance to trophic transfer. Environ. Sci. Technol. 42, 5144-5149. https://doi.org/10.1021/es800378j

Flik, G., Klaren, P.H.M., Schoenmakers, T.J.M., Bijvelds, M.J.C., 1996. Cellular calcium transport in fish: unique and universal mechanisms. Physiol. Zool. 69, 403-417.

González, V., Vignati, D. A. L., Pons, M.-N., Montarges-Pelletier, E., Bojic, C., Giamberini, L., 2015. Lanthanide ecotoxicity: First attempt to measure environmental risk for aquatic organisms. Environ. Pollut. 199, 139-147. https://doi.org/10.1016/j.envpol.2015.01.020

Gwenzi, W., Mangori, L., Danha, C., Chaukura, N., Dunjana, N., Sanganyado, E., 2018. Sources, behaviour, and environmental and human health risks of high-technology rare earth elements as emerging contaminants. Sci. Total Environ. 636, 299-313. https://doi.org/10.1016/j.scitotenv.2018.04.235

Hall, B.D., Bodaly, R.A., Fudge, R.J.P., Rudd, J.W.M., Rosenberg, D.M., 1997. Food as the dominant pathway of methylmercury uptake by fish. Water Air Soil Pollut. 100, 13-24. https://doi.org/10.1023/A:1018071406537

Handy, R.D., 1992. The assessment of episodic metal pollution. 2. The effects of cadmium and copper enriched diets on tissue contaminant analysis in rainbow trout (Oncorhynchus mykiss). Arch. Environ. Contam. Toxicol. 22, 82-87.

Hogstrand, C., Verbost, P.M., Bonga, S.E., Wood, C.M., 1996. Mechanisms of zinc uptake in gills of freshwater rainbow trout: interplay with calcium transport. Am. J. Physiol. 270, R1141-7. 
Kinraide, T.B., 2009. Improved scales for metal ion softness and toxicity. Environ. Toxicol. Chem. 28, 525-533. https://doi.org/10.1897/08-208.1

Kulaksız, S., Bau, M., 2011. Rare earth elements in the Rhine River, Germany: first case of anthropogenic lanthanum as a dissolved microcontaminant in the hydrosphere. Environ. Int. 37, 973-9. https://doi.org/10.1016/j.envint.2011.02.018

Lapointe, D., Gentes, S., Ponton, D.E., Hare, L., Couture, P., 2009. Influence of prey type on nickel and thallium assimilation, subcellular distribution and effects in juvenile fathead minnows (Pimephales promelas). Environ. Sci. Technol. 43, 8665-8670. https://doi.org/10.1021/es901929m

Ma, L., Dang, D.H., Wang, W., Evans, R.D., Wang, W.-X., 2018. Rare earth elements in the Pearl River Delta of China: Potential impacts of the REE industry on water, suspended particles and oysters. Environ. Pollut. 244, 190-201. https://doi.org/10.1016/j.envpol.2018.10.015

MacMillan, G.A., Chételat, J., Heath, J.P., Mickpegak, R., Amyot, M., 2017. Rare earth elements in freshwater, marine, and terrestrial ecosystems in the eastern Canadian Arctic. Environ. Sci. Process. Impacts 19, 1336-1345. https://doi.org/10.1039/C7EM00082K

Marshall, W.S., 2002. $\mathrm{Na}^{+}, \mathrm{Cl}^{-}, \mathrm{Ca}^{2+}$ and $\mathrm{Zn}^{2+}$ transport by fish gills: Retrospective review and prospective synthesis. J. Exp. Zool. 293, 264-283. https://doi.org/10.1002/jez.10127 
Mayfield, D.B., Fairbrother, A., 2015. Examination of rare earth element concentration patterns in freshwater fish tissues. Chemosphere 120, 68-74. https://doi.org/10.1016/j.chemosphere.2014.06.010

Misra, S., Peak, D., Chen, N., Hamilton, C., Niyogi, S., 2012. Tissue-specific accumulation and speciation of selenium in rainbow trout (Oncorhynchus mykiss) exposed to elevated dietary selenomethionine. Comp. Biochem. Physiol. - part C 155, 560-565. https://doi.org/10.1016/j.cbpc.2012.01.005

Ng, T.Y.T., Wood, C.M., 2008. Trophic transfer and dietary toxicity of Cd from the oligochaete to the rainbow trout. Aquat. Toxicol. 87, 47-59. https://doi.org/10.1016/j.aquatox.2008.01.003

Ni, I.H., Wang, W.-X., Tam, Y.K., 2000. Transfer of Cd, Cr and $\mathrm{Zn}$ from zooplankton prey to mudskipper Periophthalmus cantonensis and glassy Ambassis urotaenia fishes. Mar. Ecol. Prog. Ser. 194, 203-210. https://doi.org/10.3354/meps194203

Nieboer, E., Richardson, D.H.S., 1980. The replacement of the nondescript term "heavy metals" by a biologically and chemically significant classification of metal ions. Environ. Pollution. Ser. B, Chem. Phys. 1, 3-26. https://doi.org/10.1016/0143$148 X(80) 90017-8$

Økelsrud, A., Lydersen, E., Fjeld, E., 2016. Biomagnification of mercury and selenium in two lakes in southern Norway. Sci. Total Environ. 566-567, 596-607. https://doi.org/10.1016/j.scitotenv.2016.05.109 
Pagenkopf, G. K., 1983. Gill surface interaction model for trace-metal toxicity to fishes: role of complexation, $\mathrm{pH}$ and water hardness. Environ. Sci. Technol. 17, (6), 342347.

Perry, S.F., Flik, G., 1988. Characterization of branchial transepithelial calcium fluxes in freshwater trout, Salmo gairdneri. Am. J. Physiol. Regul. Integr. Comp. Physiol. 254, R491-R498.

Pouil, S., Warnau, M., Oberhänsli, F., Teyssié, J., Bustamante, P., Metian, M., 2016. Influence of food on the assimilation of essential elements (Co, Mn, and $\mathrm{Zn}$ ) by turbot Scophthalmus maximus. Mar. Ecol. Prog. Ser. 550, 207-218. https://doi.org/10.3354/meps 11716

Pouil, S., Warnau, M., Oberhänsli, F., Teyssié, J.L., Metian, M., 2015. Trophic transfer of ${ }^{110 \mathrm{~m}} \mathrm{Ag}$ in the turbot Scophthalmus maximus through natural prey and compounded feed. J. Environ. Radioact. 150, 189-194. https://doi.org/10.1016/j.jenvrad.2015.08.016

Rainbow, P.S., Amiard, J.C., Amiard-Triquet, C., Cheung, M.S., Zhang, L., Zhong, H., Wang, W.-X., 2007. Trophic transfer of trace metals: Subcellular compartmentalization in bivalve prey, assimilation by a gastropod predator and in vitro digestion simulations. Mar. Ecol. Prog. Ser. 348, 128-138. https://doi.org/10.3354/meps07086

Rainbow, P.S., Luoma, S.N., Wang, W.-X., 2011. Trophically available metal - A $\begin{array}{lllll}\text { variable } & \text { feast. } & \text { Environ. } & \text { Pollut. } & \text { 2347-2349, }\end{array}$ https://doi.org/10.1016/j.envpol.2011.06.040 
Rainbow, P.S., Smith, B.D., 2010. Trophic transfer of trace metals: Subcellular compartmentalisation in bivalve prey and comparative assimilation efficiencies of two invertebrate predators. J. Exp. Mar. Bio. Ecol. 390, 143-148. https://doi.org/10.1016/j.jembe.2010.05.002

Reinfelder, J. R.; Fisher, N. S., 1994. The assimilation of elements ingested by marine planktonic bivalve larvae. Limnol. Oceanogr. 39, (1), 12-20.

Sappal, R., Burka, J., Dawson, S., Kamunde, C., 2009. Bioaccumulation and subcellular partitioning of zinc in rainbow trout (Oncorhynchus mykiss): Cross-talk between waterborne and dietary uptake. Aquat. Toxicol. 91, 281-290. https://doi.org/10.1016/j.aquatox.2008.10.007

Seebaugh, D.R., Estephan, A., Wallace, W.G., 2006. Relationship between dietary cadmium absorption by grass shrimp (Palaemonetes pugio) and trophically available cadmium in amphipod (Gammarus lawrencianus) prey. Bull. Environ. Contam. Toxicol. 76, 16-23. https://doi.org/10.1007/s00128-005-0884-8

Steen Redeker, E., van Campenhout, K., Bervoets, L., Reijnders, H., Blust, R., 2007a. Subcellular distribution of $\mathrm{Cd}$ in the aquatic oligochaete Tubifex tubifex, implications for trophic availability and toxicity. Environ. Pollut. 148, 166-175. https://doi.org/10.1016/j.envpol.2006.10.031

Steen Redeker, E., van Campenhout, K., Bervoets, L., Reijnders, H., Blust, R., 2007b. Subcellular distribution of $\mathrm{Cd}$ in the aquatic oligochaete Tubifex tubifex, implications for trophic availability and toxicity. Environ. Pollut. 148, 166-175. https://doi.org/10.1016/j.envpol.2006.10.031 
Subotic, S., Spasić, S., Visnjić-Jeftić, Z., Hegedis, A., Krpo-ćetković, J., Mićković, B., Skorić, S., Lenhardt, M., 2014. Heavy metal and trace element bioaccumulation in target tissues of four edible predatory fish species from Bovan Reservoir (Serbia). Ecotoxicol. Environ. Saf. 23, 1884-1891. https://doi.org/10.1016/j.ecoenv.2013.08.020

Sun, H., Wang, X., Dai, L., Li, Z., Chen, Y., 1996. Bioconcentration and elimination of five light rare earth elements in Carp (Cyprinus carpio L.). Chemosphere $33,1475-1483$.

Tu, Q., Wang, X.-R., Li-qing, T., Le-mei, D., 1994. Bioaccumulation of the rare earth elements lanthanum, gadolinium and yttrium in carp (Cyprinus carpio). Environ. Pollut. 85, 345-350. https://doi.org/10.1016/0269-7491(94)90057-4

Wallace, W.G., Lee, B.G., Luoma, S.N., 2003. Subcellular compartmentalization of $\mathrm{Cd}$ and $\mathrm{Zn}$ in two bivalves. I. Significance of metal-sensitive fractions (MSF) and biologically detoxified metal (BDM). Mar. Ecol. Prog. Ser. 249, 183-197. https://doi.org/10.3354/meps 257125

Wallace, W.G., Lopez, G.R., 1996. Relationship between subcellular cadmium distribution in prey and cadmium trophic transfer to a predator. Estuaries 19, 923-930. https://doi.org/10.2307/1352308

Wallace, W.G., Luoma, S.N., 2003. Subcellular compartmentalization of Cd and Zn in two bivalves. II. Significance of trophically available metal (TAM). Mar. Ecol. Prog. Ser. 257, 125-137. https://doi.org/10.3354/meps257125 
Wang, W.-X., Guan, R., 2010. Subcellular distribution of zinc in Daphnia magna and implication for toxicity. Environ. Toxicol. Chem. 29, 1841-1848. https://doi.org/10.1002/etc.229

Wang, W.-X., Qiu, J.W., Qian, P.Y., 1999. The trophic transfer of Cd, Cr, and Se in the barnacle Balanus amphitrite from planktonic food. Mar. Ecol. Prog. Ser. 187, 191201. https://doi.org/10.3354/meps187191

Xu, Y., Wang, W.-X., 2002. Exposure and potential food chain transfer factor of Cd, Se and Zn in marine fish Lutjanus argentimaculatus. Mar. Ecol. Prog. Ser. 238, 173186. https://doi.org/10.3354/meps238173

Yang, X., Yin, D., Sun, H., Wang, X., Dai, L., Chen, Y., Cao, M., 1999. Distribution and bioavailability of rare earth elements. Chemosphere 39, 2443-2450. https://doi.org/10.1016/S0045-6535(99)00172-1

Zhang, L., Wang, W.-X., 2006. Significance of subcellular metal distribution in prey in influencing the trophic transfer of metals in a marine fish. Limnol. Oceanogr. 51, 2008-2017. https://doi.org/10.4319/1o.2006.51.5.2008

Zhang, W., Huang, L., Wang, W.-X., 2011. Arsenic bioaccumulation in a marine juvenile fish Terapon jarbua. Aquat. Toxicol. 105, 582-588. https://doi.org/10.1016/j.aquatox.2011.08.009 